\title{
Pre-treatment with glutamine reduces genetic damage due to cancer treatment with cisplatin
}

\author{
R.J. Oliveira ${ }^{1,2,3}$, E.S. Sassaki ${ }^{4}$, A.C.D. Monreal, M.T.F.D. Monreal ${ }^{3}$, \\ J.R. Pesarini ${ }^{1,6}$, M.O. Mauro ${ }^{1,6}$, R. Matuo ${ }^{7}$, A.F. Silva ${ }^{7}$, N.N. Zobiole ${ }^{2}$, \\ J.M. Siqueira ${ }^{2}$, L.R. Ribeiro ${ }^{6}$ and M.S. Mantovani ${ }^{7}$
}

${ }^{1}$ Centro de Estudos em Células Tronco, Terapia Celular e Genética Toxicológica, Núcleo de Hospital Universitário, Universidade Federal de Mato Grosso do Sul, Campo Grande, MS, Brasil

${ }^{2}$ Programa de Pós-Graduação em Saúde em Desenvolvimento na Região Centro-Oeste, Faculdade de Medicina "Dr. Hélio Mandetta",

Universidade Federal de Mato Grosso do Sul, Campo Grande, MS, Brasil

${ }^{3}$ Programa de Mestrado em Farmácia, Centro de Ciências Biológicas e da Saúde, Universidade Federal de Mato Grosso do Sul, Campo Grande, MS, Brasil

${ }^{4}$ Centro de Estudo em Nutrição e Genética Toxicológica (CENUGEN),

Centro Universitário Filadélfia, Londrina, PR, Brasil

${ }^{5}$ Centro de Ciências Biológicas e da Saúde,

Universidade Federal de Mato Grosso do Sul, Campo Grande, MS, Brasil

${ }^{6}$ Instituto de Biociências,

Programa de Pós-Graduação em Biologia Celular e Molecular,

Universidade Estadual Paulista, Rio Claro, SP, Brasil

${ }^{7}$ Departamento de Biologia Geral, Universidade Estadual de Londrina,

Londrina, PR, Brasil

Corresponding author: R.J. Oliveira

E-mail: rodrigo.oliveira@ufms.br

Genet. Mol. Res. 12 (4): 6040-6051 (2013)

Received March 27, 2013

Accepted August 10, 2013

Published December 2, 2013

DOI http://dx.doi.org/10.4238/2013.December.2.2

ABSTRACT. Cisplatin is an effective antineoplastic drug. However, it provokes considerable collateral effects, including genotoxic and clastogenic activity. It has been reported that a diet rich in glutamine can help inhibit such collateral effects. We evaluated this activity in 40 Swiss 
mice, distributed into eight experimental groups: G1 - Control group (PBS $0.1 \mathrm{~mL} / 10 \mathrm{~g}$ body weight); G2 - cisplatin group (cisplatin $6 \mathrm{mg} / \mathrm{kg}$ intraperitoneally); G3, G4, G5 - glutamine groups (glutamine at 150, 300, and $600 \mathrm{mg} / \mathrm{kg}$, respectively; orally); G6, G7, G8 - Pre-treatment groups (glutamine at 150,300 , and $600 \mathrm{mg} / \mathrm{kg}$, respectively; orally and cisplatin $6 \mathrm{mg} / \mathrm{kg}$ intraperitonially). For the micronucleus assay, samples of blood were collected (before the first use of the drugs at T0, then 24 (T1) and 48 (T2) hours after the first administration). For the comet assay, blood samples were collected only at $\mathrm{T} 2$. The damage reduction percentages for the micronucleus assay were $90.0,47.3$, and $37.3 \%$ at $\mathrm{T} 1$ and 46.0 , 38.6 , and $34.7 \%$ at T2, for G6, G7, and G8 groups, respectively. For the comet assay, the damage reduction percentages were 113.0, 117.4, and $115.0 \%$ for G6, G7, and G8, respectively. We conclude that glutamine is able to prevent genotoxic and clastogenic damages caused by cisplatin.

Key words: Cisplatin; Antigenotoxicity; Antimutagenicity

\section{INTRODUCTION}

The wide variations in cancer rates all over the world and changes that have occurred over time indicate that these malignancies could potentially be avoided if we know how to identify and promote changes in causal factors. For a few types of cancer, the causes are well known, but for most others, the etiologic factors are much less established. However, there are strong reasons to suspect that dietary and nutritional factors may be responsible for many of these variations observed in the rates of cancer (Willett, 2003).

There is a great deal of experimental and/or epidemiological evidence that natural constituents of foods such as carotenoids, flavonoids, isoflavones, curcumin, folic acid, monoterpenes and retinoids may also be related to a reduction in cancer risk (Flagg et al., 1995; Weisburger, 1999; Zhang et al., 1999; Weisburger, 2000; Ferrari, 2001; Ferrari and Torres, 2002; Birt et al., 2003, Willett, 2003).

These substances act in various ways in the body and can interfere with several signaling pathways, such as hormone receptors, cell cycle proteins, transcription factors, protein kinases, secondary messengers such as cAMP, enzymes such as ornithine decarboxylase, and cyclooxygenase, as well as tumor suppressor genes (Birt et al., 2003, Willett, 2003).

There have been a large number of compounds identified until now with an eventual chemopreventive activity against cancer. Among these, several are natural constituents called functional foods (Birt et al., 2003).

Presently, despite the chemotherapeutic treatments indicating improvements in the quality of life of the person attacked by cancer, they provoke innumerable adverse effect that can also compromise moreover the homeostasis in a patient.

Cisplatin is one of the more utilized chemotherapeutic agents in cancer treatment. This compound was synthesized for the first time in 1985; it is a complex of heavy metals, with two chlorine atoms and two ammonia molecules in the cis-position. This antineoplasic agent is effective in experimental chemotherapy when it is administered via the intraperitoneal route. Cisplatin can react with many cellular structures and molecules, such as membranes, 
proteins and RNA, but the main target is DNA (Antunes and Bianchi, 2004).

Chemotherapeutic regimens that include cisplatin are widely utilized in the treatment of solid tumors, especially germ-cell tumors. The main collateral effects related to these schemes are nausea and vomiting, nephrotoxicity, hypomagnesemia, peripheral neuropathy, ototoxicity, and myelosuppression. There are reports of vascular toxicity clinically revealed by coronary insufficiency (from angina up to myocardial infarction), Reynaud's phenomenon and cerebral vascular accident, demonstrating that vascular toxicity, although hardly described, can be an important collateral effect of this treatment (Rosenberg, 1985).

The antitumor action of cisplatin is attributed to its effect on DNA synthesis. However, the use of cisplatin is limited due to its toxicity to normal tissue. Cisplatin is highly clastogenic, causing sister chromatid exchange and chromosome aberrations in cultured mammalian cells, rat bone marrow cells, and peripheral blood lymphocyte of patients (Bianchi and Antunes, 1999).

In the last decades, experimental evidence has indicated that the reactive metabolites of oxygen such as superoxide $\left(\mathrm{O}_{2}^{-}\right)$, hydroxyl radical $\left(\mathrm{OH}^{-}\right)$, and hydrogen peroxide $\left(\mathrm{H}_{2} \mathrm{O}_{2}\right)$, are important damage mediators in diverse tissues and organs, including the kidney (Antunes and Bianchi, 2004).

It is thus believed that the generation of free radicals is an important mechanism in the development of cisplatin toxicity. The reactions mediated by free radicals are responsible for a series of induced chemotherapy effects, and antioxidant substances may be able to protect organs and the non-malignant cells against cytotoxic agents. Much attention has been given to the eventual hypothesis that antioxidant substances are active in protection against the toxicity caused by cisplatin in mammalian systems (Bianchi and Antunes, 1999).

Some researchers have observed that the activities of the antioxidant enzymes catalase, glutathione peroxidase and glutathione S-transferase were significantly decreased in mouse kidney and liver six days after the administration of a single dose of cisplatin. The authors considered that the increase in lipid peroxidation observed in the kidney of treated animals could have been due to the reduction in enzyme activities that protect renal tissue against the free radical attack (Antunes and Bianchi, 2004). Since glutamine is related to glutathione synthesis, glutamine supplementation can reduce the clastogenic damage caused by free radicals formed by cisplatin. Glutamine is a precursor in nucleic acid biosynthesis and is present in all cells of the body; it is found in meat, eggs, dairy products, and soy (Albertini and Ruiz, 2001).

The antioxidant activity of the amino acid glutamine has been investigated in protecting against peroxidase-mediated damage in mouse kidneys and the nephrotoxicity induced by treatment with a single dose of cisplatin at $5.0 \mathrm{mg} / \mathrm{kg}$ body weight (b.w.). The results obtained suggested that the glutamine partially protects against the lipid peroxidase damage induced by cisplatin (Mora et al., 2003).

Glutamine supplements improve protein metabolism in tumor-bearing mice receiving chemotherapy and reduce the toxicity of the chemotherapy through an improvement in glutathione production in the mice. Moreover, the oral supplementation of glutamine protects lymphocytes and attenuates intestine permeability in patients with esophagus cancer during radiochemotherapy (Yoshida et al., 1998).

Glutamine modulation of nephrotoxicity and lipid peroxidases induced by cisplatin in mice was evaluated and pre-treatment with a single oral dose of glutamine $(300 \mathrm{mg} / \mathrm{kg} \mathrm{b.w}$.) significantly inhibited the induced lipid peroxidases seven days after cisplatin administration, besides maintaining the levels of renal glutathione (Antunes and Bianchi, 2004). 
Some studies have suggested that dietary supplementation with antioxidant can influence the efficacy of the chemotherapy, such as the development of adverse effects resulting from treatment with antineoplastic agents. In a study conducted at Faculdade de Ciências Farmacêuticas de Ribeirão Preto, cisplatin was given to Wistar mice alone or after treatment with glutamine. The mice were treated with glutamine ( $300 \mathrm{mg} / \mathrm{kg}$ b.w.) administered orally (p.o.) $24 \mathrm{~h}$ before cisplatin administration $(5.0 \mathrm{mg} / \mathrm{kg}$ b.w.) intraperitoneally (i.p.) and sacrificed 24 hours after the treatment with cisplatin. Glutamine significantly reduced the clastogenic effect of cisplatin, with approximately $48 \%$ damage reduction (DR\%) in bone marrow cells. Thus, it is believed that the antioxidant action of glutamine probably modulates the clastogenic action of cisplatin (Mora et al., 2002).

According to Rouse et al. (1995), chemoterapy is limited by its toxicity to normal tissue and that glutamine protects hepatic cells from oxidative injury by increasing their glutathione levels. Oral supplementation with glutamine increases the therapeutic index of methotrexate through changes in glutathione metabolism. Thus, it is beleived that supplementation with glutamine would increase the selectivity of antitumor drugs by protecting normal tissue and possibly by sensitizing the tumor cells by the damage related to the chemotherapy.

Recently, the possible amino acid effect on nephrotoxicity and toxicity of cisplatin were investigated by Kröning et al. (2000). The authors observed that the treatment of renal epithelial cells with the amino acids methionine, DL-homocysteine and $\mathrm{N}$-acetylcysteine was inhibited by the cytotoxicity of cisplatin. Glutamine modulation of the nephrotoxicity and lipid peroxidases induced by cisplatin in mice was evaluated as well and demonstrated to be efficient (Mora et al., 2003).

In view of the previous reports, it is believed that glutamine can be effective in decreasing the adverse effects caused by the administration of cisplatin. Thus, the aim of the present study was to evaluate the influence of enteral diet, in daily pre-treatment with glutamine in the prevention of DNA damage, which can increase the predisposition to the development of cancer, caused by cisplatin.

\section{MATERIAL AND METHODS}

\section{Chemical agents}

Induction of DNA damage was carried out with cisplatin (Sigma), at a final dose of 6.0 $\mathrm{mg} / \mathrm{kg}$ and prepared in sterile phosphate-buffered saline (PBS), $\mathrm{Mg}^{2+}$ - and $\mathrm{Ca}^{2+}$-free, $\mathrm{pH}$ 7.4. Glutamine was supplied by Droganorte (Londrina, PR, Brazil) by the pharmacist Rosângela Chammé. The solutions were prepared in sterile PBS, $\mathrm{Ca}^{2+}$ - and $\mathrm{Mg}^{2+}$-free, $\mathrm{pH}$ at 7.4, for doses of 150,300 , and $600 \mathrm{mg} / \mathrm{kg}$ b.w. The doses had been determined in pilot experiments.

\section{Experimental design}

Forty male Swiss mice (Mus musculus) with an average weight of $30 \mathrm{~g}$, were obtained from the Biotério Central da Universidade Estadual de Maringá - UEM - Maringá, PR, Brazil. The experiment was conducted in the Centro de Estudos em Nutrição e Genética Toxicológica and Biotério de Nutrição Experimental do Departamento de Nutrição do Centro Universitário Filadélfia - UNIFIL - Londrina, PR, Brazil. The animals were kept separately in metabolic cages. They underwent a minimum adaptation period of seven days. Light and temperature were controlled, that is, a photoperiod of $12 \mathrm{~h}$ light: $12 \mathrm{~h}$ dark with a temperature around $22^{\circ} \mathrm{C}$. 
The animals received commercial food and filtered water ad libitum. For the experimental groups, the animals were divided into 8 groups $(\mathrm{N}=5)$ as follows: control group (G1): animals received two doses of PBS $(0.1 \mathrm{~mL} / 10 \mathrm{~g}$ b.w.), one i.p. and another p.o., simultaneously; cisplatin group (G2): animals received, simultaneously, a dose of PBS $(0.1 \mathrm{~mL} / 10 \mathrm{~g}$ b.w., p.o.) and a dose of cisplatin (6.0 mg/kg b.w., i.p.); glutamine groups (G3, G4, and G5): animals received, simultaneously, a dose of glutamine $(150,300$, and $600 \mathrm{mg} / \mathrm{kg}$ b.w., respectively, p.o.) and a dose of PBS (0.1 mL/10 g b.w.); pre-treatment groups (G6, G7, and G8): animals received a dose of glutamine $(150,300$, and $600 \mathrm{mg} / \mathrm{kg}$ b.w., respectively, p.o.) $24 \mathrm{~h}$ before receiving the cisplatin dose $(6.0 \mathrm{mg} / \mathrm{kg}$ b.w., i.p.).

The experimental groups were submitted to peripheral blood collection, for evaluation mutagenicity and antimutagenicity (micronucleous assay), by tail vein puncture at 3 different times (T0, T1, and T2). T0 corresponded to the collection that preceded any administration of drug and/or vehicle. T1 and T2 referred, respectively, to the collections at 24 and $48 \mathrm{~h}$ after the first administration of glutamine or vehicle. At T2, samples of peripheral blood for evaluation of genotoxicity and antigenotoxicity were also collected for the comet assay.

\section{Micronucleus assay}

Mutagenicity and antimutagenicity were determined by the micronucleus technique in peripheral blood as described by Hayashi et al. (1990). Accordingly, a drop of blood was deposited on a glass slide previously prepared with an acridine orange layer $(1.0 \mathrm{mg} / \mathrm{mL})$. The slide was coverslipped and placed in the freezer $\left(-20^{\circ} \mathrm{C}\right)$ for a minimum of $48 \mathrm{~h}$. The glass slides were analyzed with a fluorescence microscope, with a combined blue light $(488 \mathrm{~nm})$ and orange filter, and objective lens of 100X. A total of 2000 cells/animal were analyzed and the statistic evaluation of the data was done using the chi-square test $(\mathrm{P}<0.05)$.

\section{Comet assay}

For sample preparation, $20 \mu \mathrm{L}$ peripheral blood collected by tail vein puncture were mixed with $120 \mu \mathrm{L} 1.5 \% \mathrm{LPM}$ agarose $\left(37^{\circ} \mathrm{C}\right)$, and placed on a glass slide pre-coated with $5 \%$ normal agarose. The slides were coverslipped and cooled at $4^{\circ} \mathrm{C}$ for $20 \mathrm{~min}$. After coverslip removal, the slides were immersed in a recently prepared lysis solution composed of $89 \mathrm{~mL}$ lysis solution $(2.5 \mathrm{M} \mathrm{NaCl}, 100 \mathrm{mM}$ EDTA, $10.0 \mathrm{mM}$ Tris, $\mathrm{pH}$ 10, corrected with solid $\mathrm{NaOH}$, $890 \mathrm{~mL}$ distilled water and 1\% sodium laurylsarcosinate), $1.0 \mathrm{~mL}$ Triton X-100 (Merck) and $10 \mathrm{~mL}$ DMSO. Cells were lysed for $1 \mathrm{~h}$ at $4^{\circ} \mathrm{C}$, protected from light. Afterwards, the slides were placed in an electrophoresis chamber containing $\mathrm{pH}>13.0$ buffer $(300 \mathrm{mM} \mathrm{NaOH}$ and $1 \mathrm{mM}$ EDTA) at $4^{\circ} \mathrm{C}$ for $20 \mathrm{~min}$ for DNA denaturation. Electrophoresis was done at $25 \mathrm{~V}$ and $300 \mathrm{~mA}(1.25 \mathrm{~V} / \mathrm{cm})$. Next, the slides were neutralized with $\mathrm{pH} 7.5$ buffer $(0.4 \mathrm{M}$ Tris-HCl) for 3 cycles of $5 \mathrm{~min}$, air-dried, fixed in absolute ethanol for $10 \mathrm{~min}$ and stored for future analyses. For staining, the slides were covered with $100 \mu \mathrm{L}$ ethidium bromide $(20 \mu \mathrm{g} / \mathrm{mL})$ and coverslipped. The slides were examined under a fluorescence microscope (Nikon) at 400X magnification, with excitation filter $420-490 \mathrm{~nm}$ and barrier filter $520 \mathrm{~nm}$. We analyzed visually 100 cells per treatment, classifying the comets as: class 0 , undamaged cells with no tail; class 1 , cells with a tail smaller than the nucleoid diameter; class 2, cells with a tail size between 1 and 2 times the nucleoid diameter; and class 3 , cells with a tail bigger than 2 times the nucleoid 
diameter. Apoptotic cells, which show completely fragmented nucleoids, were not counted. The total score was calculated by the sum of the values resulting from the multiplication of all cells observed in each damage class which belonged to the class value. Statistical analysis was performed using the Student $t$-test $(\mathrm{P}<0.05)$.

\section{Calculation of damage reduction}

$\mathrm{DR} \%$ of the mutagenic agent by glutamine was calculated by taking the average number of cells with damage observed with damage-inducing agent (cisplatin) minus the number of damaged cells observed with the antimutagenicity treatment (glutamine + cisplatin) times 100, divided by the number of damaged cells observed with damage-inducing agent minus the number of damaged cells in the control group (PBS) (Manoharan and Benerjee 1985; Waters et al., 1990).

\section{RESULTS}

Table 1 presents the data for the micronucleus assay. Statistical analysis showed that at T0, in the groups G5, G6, G7 and G8 revealed a lower frequency of micronuclei when compared to their respective control groups (G1 and G2).

Table 1. Frequency, means \pm SD and DR\% for the micronucleous assay in the pre-treatment protocol.

\begin{tabular}{|c|c|c|c|c|c|c|c|c|}
\hline \multirow[t]{2}{*}{ Treatment } & \multicolumn{3}{|c|}{ Frequency of MN } & \multicolumn{3}{|c|}{ Means \pm SD } & \multicolumn{2}{|c|}{$\mathrm{DR} \%$} \\
\hline & T0 & $\mathrm{T} 1$ & $\mathrm{~T} 2$ & T0 & $\mathrm{T} 1$ & $\mathrm{~T} 2$ & $\mathrm{~T} 1$ & $\mathrm{~T} 2$ \\
\hline G1 & 43 & 23 & 22 & $8.60 \pm 3.05$ & $4.60 \pm 1.82$ & $4.40 \pm 4.00$ & - & - \\
\hline $\mathrm{G} 2$ & $29^{\mathrm{a}}$ & $133^{a *}$ & $198^{a *}$ & $5.80 \pm 2.39$ & $26.60 \pm 4.04$ & $39.60 \pm 4.98$ & - & - \\
\hline \multicolumn{9}{|c|}{ Mutagenicity } \\
\hline G3 & $20^{\mathrm{a} *}$ & $23^{\mathrm{a}}$ & $19^{\mathrm{a}}$ & $4.00 \pm 2.55$ & $4.60 \pm 2.30$ & $3.80 \pm 0.84$ & - & - \\
\hline G4 & $20^{a *}$ & $20^{\mathrm{a}}$ & $39^{a *}$ & $4.00 \pm 0.71$ & $4.00 \pm 2.24$ & $7.80 \pm 3.70$ & - & - \\
\hline G5 & $19^{a *}$ & $16^{\mathrm{a}}$ & $22^{\mathrm{a}}$ & $3.80 \pm 0.84$ & $3.20 \pm 2.28$ & $4.40 \pm 1.14$ & - & - \\
\hline \multicolumn{9}{|c|}{ Antimutagenicity } \\
\hline G6 & $9^{\mathrm{b} *}$ & $34^{\mathrm{b} *}$ & $117^{\mathrm{b} *}$ & $1.80 \pm 0.84$ & $6.80 \pm 3.35$ & $23.40 \pm 8.08$ & 90.0 & 46.0 \\
\hline G7 & $17^{\mathrm{b} *}$ & $81^{\text {b* }}$ & $130^{\mathrm{b} *}$ & $3.40 \pm 1.14$ & $16.2 \pm 8.04$ & $26.00 \pm 5.29$ & 47.3 & 38.6 \\
\hline G8 & $14^{\mathrm{b} *}$ & $92^{\mathrm{b}^{*}}$ & $137^{\mathrm{b} *}$ & $2.80 \pm 1.64$ & $18.4 \pm 2.70$ & $27.40 \pm 10.55$ & 37.3 & 34.7 \\
\hline
\end{tabular}

$\mathrm{MN}=$ micronucleus; $\mathrm{SD}=$ standard deviation; $\mathrm{DR} \%=$ damage reduction percentage; $\mathrm{G} 1$ = control; $\mathrm{G} 2$ = cisplatin $(6.0 \mathrm{mg} / \mathrm{kg}) ; \mathrm{G} 3=$ glutamine $(150 \mathrm{mg} / \mathrm{kg}$ b.w. $) ; \mathrm{G} 4=$ glutamine $(300 \mathrm{mg} / \mathrm{kg}$ b.w. $) ; \mathrm{G} 5=$ glutamine $(600 \mathrm{mg} / \mathrm{kg}$ b.w.); G6 = cisplatin $(6.0 \mathrm{mg} / \mathrm{kg})+$ Glutamine $(150 \mathrm{mg} / \mathrm{kg} \mathrm{b.w.}) ; \mathrm{G} 7=$ cisplatin $(6.0 \mathrm{mg} / \mathrm{kg})+$ Glutamine $(300 \mathrm{mg} /$ $\mathrm{kg}$ b.w. $) ; \mathrm{G} 8=$ cisplatin + Glutamine $\left(600 \mathrm{mg} / \mathrm{kg}\right.$ b.w.); ${ }^{\mathrm{a}}$ compared statistically to the $\mathrm{G} 1$; ${ }^{\mathrm{b}} \mathrm{Compared}$ statistically to the $\mathrm{G} 2 ; *$ Statistically significant difference (Chi-squared test; $\mathrm{P}<0.05$ ).

At T1, clastogenicity evaluation indicated that none of the doses had clastogenic activity. But, at T2, the intermediate dose produced a statistically significant increase in micronuclei frequency. Statistical analysis showed that at T1 and T2, there was a chemopreventive effect for all doses evaluated, but there was no dose-dependent response. DR\% was $90.0,47.3$, and $37.3 \%$ at $\mathrm{T} 1$ and $46.0,38.4$, and $34.7 \%$ for the doses of 150, 300, and $600 \mathrm{mg} / \mathrm{kg}$ b.w., respectively.

Table 2 presents the frequency of injured cells, distribution of the damage classes, score, and $\mathrm{DR} \%$ related to the comet assay in peripheral blood in the pre-treatment protocol. Statistical analysis demonstrated that glutamine had no genotoxic effect. But, the statistically significant differences observed demonstrated that supplementation with glutamine was able to reduce the frequency of basal damage observed in the control group. In evaluating antigenotoxicity, 
glutamine was found to be effective in reducing damage caused by chemotherapy treatment. $\mathrm{DR} \%$ was $113.0,117.4$, and $115.0 \%$ for doses of 150,300 , and $600 \mathrm{mg} / \mathrm{kg}$ b.w. respectively.

\begin{tabular}{|c|c|c|c|c|c|c|c|c|}
\hline \multirow[t]{3}{*}{ Treatment } & \multirow[t]{3}{*}{ Total $^{1}$} & \multicolumn{5}{|c|}{ Means \pm SD } & \multirow[t]{3}{*}{ Score } & \multirow[t]{3}{*}{ DR\% } \\
\hline & & \multirow[t]{2}{*}{ Freq. ${ }^{2}$} & \multicolumn{4}{|c|}{ Classes of DNA damage } & & \\
\hline & & & 0 & 1 & 2 & 3 & & \\
\hline G1 & 81 & $16.20 \pm 8.04$ & $83.80 \pm 8.04$ & $16.20 \pm 8.04$ & $0.00 \pm 0.00$ & $0.00 \pm 0.00$ & $16.20 \pm 8.04$ & - \\
\hline $\mathrm{G} 2$ & 380 & $76.00 \pm 7.00^{a *}$ & $24.00 \pm 7.00$ & $74.8 \pm 6.18$ & $1.20 \pm 1.30$ & $0.00 \pm 0.00$ & $77.20 \pm 7.95$ & - \\
\hline \multicolumn{9}{|c|}{ Genotoxicity } \\
\hline G3 & 22 & $4.40 \pm 20.07^{7 *}$ & $95.60 \pm 2.07$ & $4.00 \pm 2.07$ & $0.00 \pm 0.00$ & $0.00 \pm 0.00$ & $4.40 \pm 2.07$ & - \\
\hline G4 & 15 & $3.00 \pm 1.87^{* *}$ & $97.00 \pm 1.87$ & $3.00 \pm 1.87$ & $0.00 \pm 0.00$ & $0.00 \pm 0.00$ & $3.00 \pm 1.87$ & - \\
\hline G5 & 25 & $5.00 \pm 3.35^{\mathrm{a} *}$ & $95.00 \pm 3.89$ & $5.00 \pm 3.39$ & $0.00 \pm 0.00$ & $0.00 \pm 0.00$ & $5.00 \pm 3.39$ & - \\
\hline \multicolumn{9}{|c|}{ Antigenotoxicity } \\
\hline G6 & 41 & $8.20 \pm 3.27^{b *}$ & $91.8 \pm 3.27$ & $8.20 \pm 3.27$ & $0.00 \pm 0.00$ & $0.00 \pm 0.00$ & $8.20 \pm 3.27$ & 113.0 \\
\hline G7 & 29 & $5.80 \pm 1.30^{b *}$ & $94.20 \pm 1.30$ & $5.80 \pm 1.30$ & $0.00 \pm 0.00$ & $0.00 \pm 0.00$ & $5.80 \pm 1.30$ & 117.4 \\
\hline G8 & 36 & $7.20 \pm 1.79^{\mathrm{b} *}$ & $92.80 \pm 1.79$ & $7.20 \pm 1.79$ & $0.00 \pm 0.00$ & $0.00 \pm 0.00$ & $7.20 \pm 1.79$ & 115.0 \\
\hline
\end{tabular}

${ }^{1}$ Total number of damaged cells for each treatment; ${ }^{2}$ Mean number of damaged cells by treatment; SD $=$ standard deviation; DR\% = damage reduction percentages; $\mathrm{G} 1$ = control; $\mathrm{G} 2=$ cisplatin $(6 \mathrm{mg} / \mathrm{kg}) ; \mathrm{G} 3=$ glutamine $(150$ $\mathrm{mg} / \mathrm{kg}$ b.w.); G4 = glutamine (300 mg/kg b.w.); G5 = glutamine $(600 \mathrm{mg} / \mathrm{kg}$ b.w.); G6 = cisplatin (6.0 mg/kg) + Glutamine (150 mg/kg b.w.); G7 = cisplatin $(6.0 \mathrm{mg} / \mathrm{kg})+$ Glutamine $(300 \mathrm{mg} / \mathrm{kg}$ b.w. $) ; \mathrm{G} 8=$ cisplatin + Glutamine

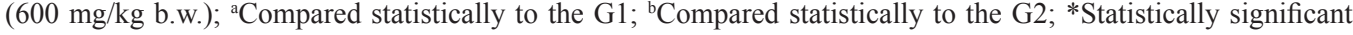
difference (Student $t$-test; $\mathrm{P}<0.05$ ).

\section{DISCUSSION}

Glutamine is present in many proteins and it is the most abundant amino acid in plasma and tissues. In human beings, glutamine represents about $20 \%$ of the free amino acids in plasma, with concentrations ranging from 0.5 to $0.9 \mathrm{mM}$. This compound is not considered an essential amino acid because the body can synthesize it.

This amino acid has stirred increasing interest because of its many metabolic roles, including the synthesis of nucleic acids and visceral protein, and glycogenesis, as wells as its functions as a glutathione antioxidant precursor, substrate for the renal ammonia production and oxidative fuel for rapidly replicating cells, such as, colonocytes, enterocytes, lymphocytes, and macrophages, whose effects seem to improve the clinical outcome of patients with cancer (Souba et al., 1990; Zeigler et al., 1990; Campos et al., 1996; Zeigler, 1996; Curi et al., 1999; Albertini and Ruiz, 2001).

During metabolic stress situations, an increase in L-glutamine utilization occurs, and so an increase in its demand, which, in the absence of exogenous supply, will be supplied by reduced protein synthesis and proteolysis, that is, either from the process of transamination or from alpha-ketoglutarate, generated in the Krebs cycle. Proteolysis increases the pool of amino acids in the intracellular environment, including glutamate by the action of glutamine synthase, it is converted to L-glutamine. Thus, two factors are noticed to cause the depletion of L-glutamine in patients with cancer: the disease progression and the catabolic effects of antineoplasic therapies (Curi et al., 1999).

Thus, in the near future, glutamine can be an important nutritional supplement to help in the maintenance of cancer patients' weight and/or can be used as a dietary antioxidant able 
to prevent clastogenic and/or genotoxic damage that could relate to the development of this disease. Another fact to be considered is the chemopreventive and antioxidant activity of this compound, since with these features it may help to reduce the side effects of chemoterapy such as DNA damage caused by free radicals generated in cells during chemotherapy.

With regard to these hypotheses, the current study assessed the pre-treatment with glutamine in the prevention of clastogenic and genotoxic damage. Before evaluating the anticlastogenicity and antigenotoxicity, the clastogenicity and genotoxicity of this substance were first studied.

In the first case, glutamine was found to be clastogenic only with the intermediate dose $(300 \mathrm{mg} / \mathrm{kg}$ b.w.), and in the evaluation of genotoxicity, none of the doses induced DNA damage. Meanwhile, all doses were effective in preventing basal damage since the frequency of comets was smaller than in the control group. In this study, chemoprotective effects of glutamine were observed at T1. In the micronucleus test, which was performed $48 \mathrm{~h}$ after the administration of glutamine or $24 \mathrm{~h}$ after the administration of cisplatin, DR\% was $90.0,47.3$, and $37.3 \%$ for doses of 150,300 and $600 \mathrm{mg} / \mathrm{kg}$ b.w., respectively. At T2, DR\% was 46.0, 38.6, and $34.7 \%$ for these same doses. Thus, it appears that the lowest dose was the dose that always showed a better activity in protecting DNA. Another interesting fact worth mentioning is that a dose-response curve is generally expected, meaning that an increase in glutamine supplementation should result in decreased DNA damage. However, the opposite was observed. For both times evaluated, reduction in damage decreased as the dose was increased. Another relevant comparison was between the times $\mathrm{T} 1$ and $\mathrm{T} 2$, where we saw a drop in $\mathrm{DR} \%$ for all doses. However, this can be explained by the 24-h difference between the blood samples, since in this period glutamine could be used in the animal for different functions, and thus, there would be reduced amounts of this amino acid, resulting in decreased chemopreventive capacity.

This chemopreventive activity corroborates the data from Oliveira et al. (2009). These authors also reported antimutagenic activity of glutamine against cisplatin; however, these studies differ in the treatment protocol. In the present study, pre-treatment was evaluated, while Oliveira et al. (2009) evaluated simple simultaneous treatment. Comparing both studies, the results showed that DR\% was higher in the simultaneous treatment protocol. T1 showed that the increase in $\mathrm{DR} \%$ was $1.06,1.94$, and 2.59 times comparing simultaneous treatment protocol and pre-treatment for doses of 150,300 , and $600 \mathrm{mg} / \mathrm{kg}$, respectively. As for the increasing chemopreventive activity at $\mathrm{T} 2$, ratios were $1.67,1.59$, and 1.64 for the same doses.

For the evaluation of antigenotoxicity, it was observed that all doses were effective. However, there was again no dose-response relation. This test showed that the most effective dose was the intermediate dose. The same conclusion was drawn by Oliveira et al. (2009). According to these authors, the antigenotoxic activity in simultaneous treatment was 115.0 to $117.0 \%$. However, in the present study, DR\% in pre-treatment ranged from 113.0 to $117.4 \%$. These data suggest that the treatment protocol did not have an influence on the DR\% of the antigenotoxic assay (comet), unlike in the antimutagenicity assay (micronucleus).

In another study, Tavares et al. (1998) showed the antimutagenic activity of glutamine against damage caused by doxorubicin by in vivo and in vitro assays. The authors did not observe significant differences in the frequency of chromosomal aberrations or number of cells with chromosomal aberrations, when compared to untreated animals. This lack of mutagenic activity was also observed in assays with the $\mathrm{CHO}$ cell line. In the same study, damage reduction calculated showed prevention of $57.7 \%$ in an in vivo assay and $84.2 \%$ in an in vitro assay. We can assume that these data corroborate our findings, since the damage reduction ranged 
from 37.3 to $90.0 \%$ at $\mathrm{T} 1$ and 34.7 to 46.0 at $\mathrm{T} 2$. Despite that the values are not the same, chemopreventive activity for all assays was observed.

According to Flora and Zilberstein (2000), glutamine is an amino acid that takes part in nitric oxide biosynthesis. Thus, the supplementation of high doses of this amino acid could produce an increase in this oxide in the intracellular environment and this could lead to an increased number of micronuclei. Thus, this fact would really help the understanding of the decrease in damage with increased dose of glutamine, observed in the micronucleus test. However, the same analogy could not be made in the comet assay, since in this test the DR\% values were very close.

The functions of nitric oxide are often antagonistic, since this molecule has beneficial or potentially toxic effects (Flora and Zilberstein, 2000). Nitric oxide is an important intracellular messenger in mammals. The mechanism of intercellular signaling is generally done by transmembrane receptors that unleash cascades of intracellular signals that will create a change in the cell. But, due to high diffusibility of nitric oxide, its signals are directly executed at the intracellular level. This compound is also part of the body's first defense with microbicide power (Drapier et al., 1988; Gazzinelli et al., 1992; Feng and Walker, 1993; Oswald et al., 1994; Flora and Zilberstein, 2000). There is a tenuous limit of tissue nitric oxide concentration between non-toxicity to the host cells and toxicity necessary for antimicrobicide action. In the case of autoimmune diseases and situations of exaggerated overload, nitric oxide in the body is in toxic concentrations to the normal cells. According to studies, nitric oxide has toxic effects in different tissues. However, it is necessary to report that the toxic effects include: (I) septic shock, (II) inflammation, (III) reperfusion syndrome after ischemia, (VI) microvascular fluid leak, (V) arteriosclerosis, (VI) autoimmune alveolitis, (VII) glomerulonephritis, (VIII) neurotoxicity, (IX) increased irritability, (X) migraine, (XI) hyperalgesia, and (XII) destruction of beta cells. But, it is necessary to highlight the nitric oxide effects on the intestine where there is mainly occurrence of digestive hemorrhage and mutagenic damage (Flora and Zilberstein, 2000).

According to the protocol used and relevant literature, it is supposed that the glutamine has the capacity to modulate the mechanism of cell repair, since the administration of glutamine prior to cisplatin could lead to DNA protection by forming a kind of protective cover or increase the fidelity of the repair mechanism. Thus, this would describe a bioantimutagenic mechanism for this amino acid.

According to studies, glutamine shows antioxidant activity (Albertini and Ruiz, 2001; Antunes and Bianchi, 2004) and can act in different ways such as blockers preventing the activity of carcinogens or tumor promoters from reaching the target tissue by several mechanisms or a combination of them. The interference mechanisms of antioxidants can involve the capture and/or sequestering of reactive carcinogens or induce the activity of enzymes systems that detoxify the carcinogens, even blocking cellular events necessary for the promotion of the tumor (Wattenberg, 1992). However, according to Mora et al. (2002), glutamine can also promote improvements in repair mechanisms. Thus, it has been shown that glutamine when administered prior to chemotherapy can be effectively used to produce energy for the maintenance of cell repair mechanisms and still provide nitrogen for the production of nucleotides (Déchelotte et al., 1991; Mora et al., 2002).

According to Newsholme et al. (1985), the nitrogen of the amine group can increase the bioavailability of nucleotides which would facilitate the process and the effectiveness of DNA repair. Considering these chemoprotective activities, it is necessary to know the two types of substances capable of preventing damage to DNA, that is, the dismutagenic and bioantimutagenic substances. 
Bioantimutagenics substances act by modulating DNA repair and replication. They act at the cellular level by increasing replication fidelity, stimulating repair free of error or inhibiting repair systems subject to error (Hartman and Shankel, 1990; De Flora, 1998; Simic et al., 1998).

Dismutagenic substances are able to inactivate a mutagenic agent and are characterized by the action of the compound directly on the mutagenic agent or its precursors, inactivating them chemically or enzymatically (Kada and Shimoi, 1987; Hartman and Shankel, 1990; Ferguson, 1994; De Flora, 1998).

On the basis of these reports, it is believed that glutamine may actually be beneficial in preventing genetic damage preventiont and the development of cancer. Supporting this hypothesis, Yoshida et al. (2001) indicates that the depletion of glutamine occurs in the host tissue (in this case mice with cancer), and its supplementation could lead to reducing muscle protein loss, in addition to protecting immune function and the intestinal barrier during chemotherapy and radiotherapy.

Studies also indicate that pre-treatment with glutamine may increase intracellular glutathione, intensifying protection against damage induced by free radicals that can react with DNA (Mora et al., 2003).

The oral administration of L-glutamine before, during and after chemotherapy is feasible and is possibly associated with a higher tolerance to treatment with antineoplasic agents (Curi et al., 1999). During radiotherapy, treatment with glutamine can accelerate the healing process of the irradiated intestine and prevent against injuries, and furthermore reduce the complications arising from enteropathy caused by radiotherapy. Finally, glutamine seems to make tumor cells more sensitive to chemo- and radiotherapy, by reducing the intracellular concentrations of L-glutamine from other host tissues. It is unlikely that other antioxidants, contrary to L-glutamine, also raise the concentration of L-glutamine in cancer cells, increasing the resistance of the tumor to therapy. This feature can improve the patient's clinical picture and, consequently, the morbidity and mortality rates linked to cancer and antineoplasic therapies (Klimberg et al., 1990).

In view of all these considerations, it is inferered that glutamine is able to prevent genotoxic and clastogenic damage. However, it is apparent that more studies are needed to characterize the efficiency of glutamine in preventing genetic damage that would lead to the development of cancers, as well to assess its ability to reduce the side effects of chemotherapy, as these can also lead to genotoxic and/or clastogenic damage to non-tumor cells and eventually cause death. Considering these findings and appropriate nutritional guidance, perhaps in the near future, the administration of glutamine along with chemotherapy can assist in improving patients' quality of life.

\section{ACKNOWLEDGMENTS}

Research supported by Pró-Reitoria de Pesquisa e Pós-Graduação - Centro Universitário Filadélfia (UniFil), Fundação Araucária: Apoio ao Desenvolvimento Científico e Tecnológico do Paraná and "Fundação de Apoio ao Desenvolvimento do Ensino, Ciência e Tecnologia" (FUNDECT) of the State of Mato Grosso do Sul.

\section{REFERENCES}

Albertini SM and Ruiz MA (2001). O papel da glutamina na terapia nutricional do transplante de medula óssea. Rev. Bras. Hematol. Hemoter. 23: 41-47. 
Antunes LMG and Bianchi MLP (2004). Antioxidantes da dieta como inibidores da nefrotoxicidade induzida pelo antitumoral cisplatina. Rev. Nutr. 17: 89-96.

Bianchi MLP and Antunes LMG (1999). Radicais livres e os principais antioxidantes da dieta. Rev. Nutr. 12: 123-130.

Birt DF, Shull JD and Yaktine AL (2003). Quimioprevenção do Câncer. In: Tratado de Nutrição Moderna na Saúde e na Doença (Shils ME, Olson JA, Shike M and Ross AC, eds.). Monole, Barueri, 1349-1384.

Campos FG, Waitzerberg DL, Logulo AF, Mucerino DR, et al. (1996). Importância da glutamina em nutrição na prática clínica. Arq. Gastroenterol. 33: 86-92.

Curi R, Newsholme P, Pithon-Curi TC, Pires-de-Melo M, et al. (1999). Metabolic fate of glutamine in lymphocytes, macrophages and neutrophils. Braz. J. Med. Biol. Res. 32: 15-21.

De Flora S (1998). Mechanisms of inhibitors of mutagenesis and carcinogenesis. Mutat. Res. 402: 151-158.

Déchelotte P, Darmaun D, Rongier M, Hecketsweiler B, et al. (1991). Absorption and metabolic effects of enterally administered glutamine in humans. Am. J. Physiol. 260: G677-G682.

Drapier JC, Wietzerbin J and Hibbs JB Jr (1988). Interferon-gamma and tumor necrosis factor induce the L-argininedependent cytotoxic effector mechanism in murine macrophages. Eur. J. Immunol. 18: 1587-1592.

Feng HM and Walker DH (1993). Interferon-gamma and tumor necrosis factor-alpha exert their antirickettsial effect via induction of synthesis of nitric oxide. Am. J. Pathol. 143: 1016-1023.

Ferguson LR (1994). Antimutagens as cancer chemopreventive agents in the diet. Mutat. Res. 307: 395-410.

Ferrari CKB (2001). Oxidative stress pathophysiology: searching for an effective antioxidant protection. Int. Med. J. 8: $175-184$.

Ferrari CKB and Torres EAFS (2002). New dietetic compounds with anticarcinogenic properties. Rev. Bras. Cancerol. 48: 375-382.

Flagg EW, Coates RJ and Greenberg RS (1995). Epidemiologic studies of antioxidants and cancer in humans. J. Am. Coll. Nutr. 14: 419-427.

Flora R and Zilberstein B (2000). Óxido nítrico: o simples mensageiro percorrendo a complexidade. Metabolismo, síntese e funções. Rev. Assoc. Med. Bras. 46: 265-271.

Gazzinelli RT, Oswald IP, Hieny S, James SL, et al. (1992). The microbicidal activity of interferon-gamma-treated macrophages against Trypanosoma cruzi involves an L-arginine-dependent, nitrogen oxide-mediated mechanism inhibitable by interleukin-10 and transforming growth factor-beta. Eur. J. Immunol. 22: 2501-2506.

Hartman PE and Shankel DM (1990). Antimutagens and anticarcinogens: a survey of putative interceptor molecules. Environ. Mol. Mutagen. 15: 145-182.

Hayashi M, Morita T, Kodama Y, Sofuni T, et al. (1990). The micronucleus assay with mouse peripheral blood reticulocytes using acridine orange-coated slides. Mutat. Res. 245: 245-249.

Kada T and Shimoi K (1987). Desmutagens and bio-antimutagens - their modes of action. Bioessays 7: 113-116.

Klimberg VS, Souba WW, Salloum RM, Plumley DA, et al. (1990). Glutamine-enriched diets support muscle glutamine metabolism without stimulating tumor growth. J. Surg. Res. 48: 319-323.

Kröning R, Lichtenstein AK and Nagami GT (2000). Sulfur-containing amino acids decrease cisplatin cytotoxicity and uptake in renal tubule epithelial cell lines. Cancer Chemother. Pharmacol. 45: 43-49.

Manoharan K and Banerjee MR (1985). beta-Carotene reduces sister chromatid exchanges induced by chemical carcinogens in mouse mammary cells in organ culture. Cell Biol. Int. Rep. 9: 783-789.

Mora LO, Antunes LM, Francescato HD and Bianchi ML (2002). The effects of oral glutamine on cisplatin-induced genotoxicity in Wistar rat bone marrow cells. Mutat. Res. 518: 65-70.

Mora LO, Antunes LM, Francescato HD and Bianchi ML (2003). The effects of oral glutamine on cisplatin-induced nephrotoxicity in rats. Pharmacol. Res. 47: 517-522.

Newsholme EA, Crabtree B and Ardawi MS (1985). Glutamine metabolism in lymphocytes: its biochemical, physiological and clinical importance. Q J. Exp. Physiol. 70: 473-489.

Oliveira RJ, Baise E, Mauro MD, Pesarini JR, et al. (2009). Evaluation of chemopreventive activity of glutamine by the comet and the micronucleus assay in mice's peripheral blood. Environ. Toxicol. Pharmacol. 28: 120-124.

Oswald IP, Eltoum I, Wynn TA, Schwartz B, et al. (1994). Endothelial cells are activated by cytokine treatment to kill an intravascular parasite, Schistosoma mansoni, through the production of nitric oxide. Proc. Natl. Acad. Sci. U. S. A. 91: 999-1003.

Rosenberg B (1985). Fundamental studies with cisplatin. Cancer 55: 2303-2315.

Rouse K, Nwokedi E, Woodliff JE, Epstein J, et al. (1995). Glutamine enhances selectivity of chemotherapy through changes in glutathione metabolism. Ann. Surg. 221: 420-426.

Simic D, Vukovic-Gacic B and Knezevic-Vukcevic J (1998). Detection of natural bioantimutagens and their mechanisms of action with bacterial assay-system. Mutat. Res. 402: 51-57.

Souba WW, Klimberg VS, Plumley DA, Salloum RM, et al. (1990). The role of glutamine in maintaining a healthy gut 
and supporting the metabolic response to injury and infection. J. Surg. Res. 48: 383-391.

Tavares DC, Cecchi AO, Antunes LM and Takahashi CS (1998). Protective effects of the amino acid glutamine and of ascorbic acid against chromosomal damage induced by doxorubicin in mammalian cells. Teratog. Carcinog. Mutagen. 18: 153-161.

Waters MD, Brady AL, Stack HF and Brockman HE (1990). Antimutagenicity profiles for some model compounds. Mutat. Res. 238: 57-85.

Wattenberg LW (1992). Inhibition of carcinogenesis by minor dietary constituents. Cancer Res. 52: 2085s-2091s.

Weisburger JH (1999). Mechanisms of action of antioxidants as exemplified in vegetables, tomatoes and tea. Food Chem. Toxicol. 37: 943-948.

Weisburger JH (2000). Eat to live, not live to eat. Nutrition 16: 767-773.

Willett WC (2003). Dieta, Nutrição e Prevenção do Câncer. In: Tratado de Nutrição Moderna na Saúde e na Doença (Shils ME, Olson JA, Shike M and Ross AC, eds.). Monole, Barueri, 1329-1340.

Yoshida S, Matsui M, Shirouzu Y, Fujita H, et al. (1998). Effects of glutamine supplements and radiochemotherapy on systemic immune and gut barrier function in patients with advanced esophageal cancer. Ann. Surg. 227: 485-491.

Yoshida S, Kaibara A, Ishibashi N and Shirouzu K (2001). Glutamine supplementation in cancer patients. Nutrition 17: 766-768.

Zhang S, Hunter DJ, Forman MR, Rosner BA, et al. (1999). Dietary carotenoids and vitamins A, C, and E and risk of breast cancer. J. Natl. Cancer Inst. 91: 547-556.

Ziegler TR, Benfell K, Smith RJ, Young LS, et al. (1990). Safety and metabolic effects of L-glutamine administration in humans. JPEN J. Parenter. Enteral. Nutr. 14: 137S-146S.

Ziegler TR (1996). Glutamine supplementation in catabolic illness. Am. J. Clin. Nutr. 64: 645-647. 